Małgorzata Piasecka ORCID: 0000-0001-9532-489X

Uniwersytet Jagielloński

Łukasz Szwejka ORCID: 0000-0001-5168-3372

Uniwersytet Jagielloński

\title{
Profilaktyka w miejscu pracy jako praktyka oparta na dowodach naukowych
}

\author{
Prevention in the Workplace as an \\ Evidence-based Practice
}

\begin{abstract}
ABSTRAKT
Zaangażowanie w tworzenie bezpiecznego i zdrowego miejsca efektywnej pracy powinno być celem każdego pracodawcy bez względu na wielkość przedsiębiorstwa. Używanie przez pracowników środków odurzajqcych, substancji psychotropowych, środków zastępczych i/lub nowych substancji psychoaktywnych w celach innych niż medyczne może mieć negatywny wpływ na bezpieczeństwo i prawidłowe wykonywanie pracy, a tym samym stanowić szeroko rozumiane zagrożenie zarówno dla pracownika, jak i przedsiębiorstwa. W obliczu zagrożenia uzależnieniem pracowników, a tym samym obniżenia się jakości ich życia oraz efektywności wykonywanej pracy, istotne staje się pytanie o warunki skuteczności prowadzonych oddziaływań z zakresu profilakłyki społecznej w środowisku zatrudnienia. Jasno określone cele dostosowane do potrzeb odbiorców, różne rodzaje prowadzonych działań oraz akcji promocyjnych to istotne elementy, które powinny być uwzględnione przy budowaniu
\end{abstract}

SLOWA KLUCZOWE profilaktyka społeczna, środowisko pracy, substancje psychoaktywne, uzależnienie, praktyka oparta na dowodach

\section{KEYWORDS}

social prevention, workplace, psychoactive substances, addiction, evidence-based practice

SPI Vol. 22, 2019/3

ISSN 2450-5358

e-ISSN 2450-5366

DOI: 10.12775/SPI.2019.3.004

Nadesłano: 31.07.2019

Zaakceptowano: 3.11.2019

Artykuły i rozprawy 
wewnętrznej polityki ograniczania konsumpcji substancji psychoaktywnych przez pracowników. Celem niniejszego artykułu jest prezentacja współczesnych strategii z zakresu profilaktyki używania środków psychoaktywnych w miejscu pracy, które zgodnie z wiedzq naukowa (dowodami empirycznymi) odznaczaja się wysokq skutecznościq. W tym celu dokonano analizy dostępnej literatury przedmiotu.

\section{ABSTRACT}

A commitment to the creation of safe and healthy workplace should be the goal of every employer, regardless of the size of the company. The employees' use of intoxicants, psychotropic substances and drugs for purposes other than medical may have a negative impact on work safety, and thus constitute a broadly understood threat for both the employee and the company. Threatened by employee addiction and a decrease in the quality of their life and work efficiency, the question about the effectiveness of social prevention treatment in the workplace is crucial. Clearly defined goals, preventive actions tailored to the needs of recipients and collateral activities including promotional ones, are important elements that should be taken into account when building an internal policy of limiting the consumption of psychoactive substances by employees. The purpose of this article is to present contemporary prevention strategies of psychoactive substance use in the workplace. According to the scientific knowledge (empirical evidence), these strategies are characterized by their high effectiveness. To this end, the available literature was analyzed.

\section{Wstęp}

Celem artykułu jest określenie standardów oddziaływań z zakresu profilaktyki sięgania po nielegalne substancje psychoaktywne przez pracowników w miejscu pracy. Obecnie zjawisko sięgania po narkotyki przez dzieci, młodzież i osoby dorosłe, pomimo tego, że nie ma tendencji wzrostowych, nadal pozostaje na niepokojącym poziomie. Prowadzone są liczne programy profilaktyczne, zarówno na poziomie uniwersalnym, selektywnym, jak i wskazującym, w szkołach, świetlicach środowiskowych, środowisku lokalnym, adresowane zarówno do dzieci, młodzieży, młodych dorosłych oraz do rodziców. Zgodnie z europejskim raportem narkotykowym z 2019 roku, około 
29\% osób w wieku od 15 do 64 lat w Unii Europejskiej przynajmniej raz w życiu spróbowało narkotyków. Powszechnym zjawiskiem wśród osób ich używających jest jednoczesne przyjmowanie różnych substancji. Najczęściej zażywanymi substancjami odurzającymi są konopie indyjskie. Wszystkie rodzaje narkotyków są częściej używane przez mężczyzn, a różnica ta jest szczególnie wyraźna w przypadku bardziej intensywnego lub regularnego używania (Europejski raport narkotykowy 2019: 43-44). Raport krajowy o stanie narkomanii w Polsce z 2018 roku wskazuje, że w odsetek osób w wieku 15-64 lata spożywających alkohol wyniósł 89,7\% (badanie z 2014 roku), natomiast w przypadku narkotyków - 4,7\%. Wśród młodych dorosłych (15-34 lata) rozpowszechnienie zażywania narkotyków sięgało poziomu około 10\%. Marihuana była najczęściej zażywanym narkotykiem. Przyznało się do tego 10\% badanych w wieku 15-34 lata (2014 rok). W całej badanej populacji (15-64 lata) wyższy odsetek odnotowano wśród mężczyzn - 15,4\% niż wśród kobiet - 3,7\% ( $R a$ port o stanie narkomanii 2018: 7-8). Powyższe dane wskazują, że zjawisko sięgania po narkotyki dotyczy również osób będących w wieku produkcyjnym, zatem pracujących lub też pozostających w stosunku pracy. Działania profilaktyczne w tym obszarze są jednak mocno ograniczone i istnieje deficyt rekomendowanych programów, których celem byłaby minimalizacja zjawiska sięgania po środki psychoaktywne w miejscu pracy.

Zgodnie z badaniami Krajowego Centrum Promocji Zdrowia w Miejscu Pracy przy Instytucie Medycyny Pracy im. prof. Jerzego Nofera w Łodzi, firmy nie angażują się w jakiekolwiek działania dotyczące sięgania po narkotyki przez pracowników (Korzeniowska, Puchalski, Goszczyńska 2013: 7). Badania zrealizowane na przełomie listopada i grudnia 2015 roku (objęto nimi 1000 zakładów pracy z terenu całej Polski, zatrudniających co najmniej 50 pracowników), których celem było rozpoznanie aktywności średnich i dużych przedsiębiorstw w Polsce w zakresie promocji zdrowia pracowników (w tym przeciwdziałania używaniu substancji psychoaktywnych), wykazały, że w firmach profilaktyka używania narkotyków jest prawie w ogóle nierealizowana. Jedynie 1,2\% firm zauważyło oznaki problemów związanych $\mathrm{z}$ takimi substancjami, natomiast tylko 0,5\% uznało je za istotne i podjęło jakiekolwiek działania (Puchalski, Korzeniowska 2017: 234). Dodatkowo zakłady pracy w Polsce mają 
niewystarczające wsparcie we wdrażaniu działań służących ograniczeniu zjawiska sięgania po nielegalne substancje psychoaktywne przez pracowników medycyny pracy, jak i samorządów gminnych (Goszczyńska 2013: 593-594).

W Polsce nie istnieją również programy rekomendowane przez Krajowe Biuro ds. Przeciwdziałania Narkomanii, które byłyby dedykowane do pracowników i miałyby być realizowane w środowisku pracy. Zauważa się także deficyt widoczny na polu badań naukowych w tym zakresie. Obszar miejsca pracy wydaje się mało zagospodarowany pod kątem badań dotyczących diagnozy skali zjawiska zażywania środków psychoaktywnych przez pracowników, potrzeb związanych z oddziaływaniami profilaktycznymi w kontekście ich zażywania oraz różnego rodzaju uwarunkowań i modeli. Deficyt istnieje również $\mathrm{w}$ prowadzonych programach profilaktycznych oraz ich ewaluacji na terenie zakładów pracy.

\section{Negatywne skutki zażywania nielegalnych substancji psychoaktywnych w miejscu pracy}

Zażywanie narkotyków jest jedną z przyczyn obciążenia chorobami w skali ogólnoświatowej. $Z$ zażywaniem narkotyków moga współwystępować problemy zdrowotne o charakterze ostrym lub przewlekłym, na które dodatkowy wpływ mają liczne czynniki (zależne od właściwości danej substancji, sposobu ich podania, wytrzymałości organizmu oraz kontekstu społecznego, w którym odbywa się konsumpcja narkotyku). Przewlekłe problemy zdrowotne obejmują m.in. uzależnienie oraz choroby zakaźne związane z przyjmowaniem narkotyków. Wśród stanów ostrych najlepiej udokumentowanym jest przedawkowanie (Europejski raport narkotykowy 2019: 65). Według danych Głównego Urzędu Statystycznego z 2016 roku w Polsce zarejestrowano 204 zgony, a w 2015 roku - 255 zgonów, których przyczyną były narkotyki. Dane z 2016 roku podają, że ofiarami śmiertelnych przedawkowań w Polsce są głównie mężczyźni (72\% przypadków) (Raport o stanie narkomanii 2018: 11). Według badań prowadzonych przez Instytut Psychiatrii i Neurologii w Warszawie standaryzowany współczynnik umieralności wynosi 3,4 (2,1 dla kobiet i 4,6 dla mężczyzn). Współczynnik ten przybiera najwyższe wartości dla kobiet w kategorii wiekowej: 30-34 lata $(18,5)$. Z badań 
wynika, że prawdopodobieństwo zgonu jest 3,4 razy wyższe wśród osób zażywających narkotyki niż w całej populacji (Raport o stanie narkomanii 2018: 14-15).

Oszacowanie wielkości strat produkcyjnych spowodowanych przedwczesną śmiercią w wyniku przedawkowania narkotyku wskazuje, że gdyby użytkownicy narkotyków przeżyli jeszcze jeden rok, mogliby w tym roku dodatkowo wytworzyć PKB o wartości około 46,94 mln zł, w tym użytkownicy opioidów - o wartości około 9,47 mln zł (Mielecka-Kubień 2017: 28).

Jednym z najpoważniejszych problemów zdrowotnych o charakterze przewlekłym są choroby zakaźne. W 2017 roku rozpoznano 1310 nowych przypadków zakażeń HIV, w tym 36 wśród iniekcyjnych użytkowników narkotyków. Dane zebrane przez Narodowy Instytut Zdrowia Publicznego w 2017 roku wśród iniekcyjnych użytkowników narkotyków wskazały, że przeciwciała anty-HIV występowały u 18,5\% badanych przyjmujących narkotyki w iniekcjach, a przeciwciała anty-HCV u 57,6\% badanych (Raport o stanie narkomanii 2018: 14-15).

Poza kosztami ponoszonymi przez samych użytkowników narkotyków, straty ponosi również społeczeństwo, w tym także pracodawcy. Wartość oszacowanych strat produkcyjnych w 2015 roku z tytułu absencji chorobowej osób zażywających narkotyki wyniosła $32,25 \mathrm{mln}$ zł. Taką wartość PKB mogłyby wypracować osoby biorące narkotyki i jednocześnie będące na zwolnieniu lekarskim (przy założeniu, że wypracowałyby w roku 2015 tyle dni, co inne zdrowe osoby i wytworzyłyby taką samą wartość PKB w ciągu jednego dnia) (Mielecka-Kubień 2017: 47). Osoby zażywające narkotyki mogą również stanowić zagrożenie dla siebie samych, jak i innych osób, poprzez m.in. prowadzenie pojazdu pod wpływem działania narkotyku. 1,7\% dorosłych Polaków, którzy w ciągu ostatnich 30 dni przed badaniem prowadzili pojazdy mechaniczne, zadeklarowało, że robili to pod wpływem alkoholu, a 1,1\% dorosłych Polaków przyznało się, że prowadzili pod wpływem narkotyku (Raport o stanie narkomanii 2018: 14-20). Konsekwencjami wynikającymi z takich działań są nie tylko straty w postaci pogorszenia wizerunku firm, której pracownik może spowodować wypadek, lecz przede wszystkim zagrożenie utraty zdrowia lub życia potencjalnych ofiar wypadków drogowych spowodowanych przez nietrzeźwych kierowców. 
Możemy zatem stwierdzić, że istnieje wiele powodów, w tym poważne ekonomiczne straty, które powinny zwiększyć zaangażowanie firm w zapobieganie zażywania narkotyków przez pracowników. Nadużywanie substancji wiąże się z nieobecnością w pracy, zwiększonym ryzykiem urazów i wypadków w pracy, stratami wynikającymi z opieki zdrowotnej (Cook, Schlenger 2002: 117-118). Zażywanie substancji psychoaktywnych przez pracowników może również prowadzić do zwiększenia skali rotacji miejsc pracy, powtarzającej się absencji wynikającej ze zwolnień lekarskich, może dodatkowo osłabiać relacje i zwiększać napięcie wśród pracowników, zwłaszcza jeśli podejrzewają, że nieobecność jest powiązana z zażywaniem narkotyku (Van Hasselt, Keyes, Bray, Miller 2015: 381). W wyniku sięgania po narkotyki przez pracowników mogą powstać różnego rodzaju zaburzenia $\mathrm{w}$ komunikacji wynikające $\mathrm{z}$ gwałtownych i nieprzewidywalnych wahań nastroju, drażliwości i agresji, nieodpowiedzialne zachowania, nieostrożne i irracjonalne wybory oraz ogólny brak zainteresowania sprawami firmy. Wszystkie te poznawcze i behawioralne przejawy są wyraźnie szkodliwe dla firm (Breen, Matusitz 2009: 436).

Nieefektywne radzenie sobie z problemem sięgania po substancje psychoaktywne przez pracowników w miejscu pracy generuje też koszty dla firm wynikające $z$ ograniczania się pracownika jedynie do fizycznej obecności na stanowisku pracy, obniżania produktywności, zwiększania ilości popełnianych błędów, pogarszania się wizerunku firmy oraz spadku zaufania klientów. Wdrożenie kompleksowej polityki oraz świadomego podejścia do problemu narkotyków w miejscu pracy może zminimalizować ryzyko ponoszenia przez firmę kosztów (Informator dla zaktadów pracy... 10).

Biorąc pod uwagę ponoszone konsekwencje zarówno przez pracodawcę, jak i pracownika, wynikające $\mathrm{z}$ zażywania nielegalnych substancji psychoaktywnych przez personel firmy, nie powinno być niczym szczególnym wprowadzanie przez zespół zarządzający polityki antynarkotykowej oraz programów i działań na niej bazujących, a mających na celu zminimalizowanie zjawiska sięgania po narkotyki. W rzeczywistości jednak działania takie są prowadzone przez nieliczne firmy.

Programy profilaktyczne oparte na dowodach naukowych mogłyby w skuteczny sposób ograniczyć ryzykowne zachowania pracowników, a tym samym zminimalizować koszty ponoszone przez 
jednostkę oraz pracodawcę. Działania prowadzone w nurcie evidence-based practice to takie działania, które zostały naukowo przetestowane i poddane ocenom klinicznym, w wyniku czego zostały uznane za skuteczne (Sorensen, Hettema, Larios 2018). Zatem inwestycja w profilaktykę prowadzoną w tym nurcie może skutkować wymiernymi korzyściami dla całego zespołu danego zakładu pracy.

\section{Polityka antynarkotykowa w miejscu pracy}

Czynniki psychospołeczne w miejscu pracy mogą wpływać na zażywanie narkotyków przez pracowników. Wśród takich czynników wymienić można: środowisko pracy, procesy grupowe, postrzeganie i tolerancję współpracowników, którzy używają alkoholu lub narkotyków oraz postawy wobec polityki firmy. Czynniki te moga być postrzegane wzdłuż kontinuum makroorganizacyjnych wpływów (środowisko pracy) na wpływy mikropsychologiczne (postawy). Czynnikami ochronnymi są integracja społeczna i porządek organizacyjny w miejscu zatrudnienia. Problematyczne używanie substancji prowadzi do konieczności opracowania polityki, którą rozwija się w celu kontrolowania lub rozwiązywania problemów (Bennett, Lehman, Reynolds 2000: 159).

Strategie narkotykowe koncentrują się na opracowaniu i wdrażaniu skutecznych reakcji na problemy narkotykowe w oparciu o dowody naukowe. Działania z obszaru profilaktyki oraz wczesnej interwencji maja na celu zapobieganie przyjmowaniu narkotyków oraz powstawaniu związanych z tym problemów (Europejski raport narkotykowy 2019: 66). Działania z zakresu przeciwdziałania narkomanii w Polsce określa Ustawa o przeciwdziałaniu narkomanii z 29 lipca 2005 roku. Krajowa strategia przeciwdziałania narkomanii określona jest w Narodowym Programie Zdrowia (NPZ), który obejmuje zagadnienie uzależnień oraz zapobiegania używaniu różnych substancji psychoaktywnych. Dzięki temu tematyka uzależnień została ujęta w szerszym kontekście zdrowia publicznego. Ważnym elementem NPZ jest zwiększony nacisk na poprawę jakości programów profilaktycznych. Działania profilaktyczne są w naszym kraju realizowane przez wiele podmiotów, w tym przede wszystkim przez jednostki administracji rządowej (właściwe ministerstwa i podległe 
agencje), samorządy lokalne i regionalne oraz organizacje pozarządowe (Raport o stanie narkomanii 2018: 28, 33-34).

Zdecydowana polityka stanowi podstawę dobrych praktyk w zakresie promowania zdrowia psychicznego w miejscu pracy. Polityka ta powinna obejmować rygorystyczne przepisy znane wszystkim pracownikom oraz charakteryzować się przejrzystym budżetem. W jej ramach winna być również wyznaczona i wyszkolona osoba bądź grupą osób posiadających konieczne umiejętności, które byłyby następnie odpowiedzialne za jej wdrożenie. Wreszcie zespół zarządzający winien być odpowiednio silny i mieć duże wsparcie ze strony pracowników. W ramach tej polityki powinny być uwzględnione obszary takie jak: zdrowie i bezpieczeństwo, promocja zdrowia, rehabilitacja i powrót do pracy, równość i niedyskryminacja (Wynne, De Broeck, Vandenbroek, Leka, Jain, Houtman, McDaid 2014: 27-28).

Punktem wyjścia dla opracowania i wdrożenia polityki antynarkotykowej $\mathrm{w}$ firmie jest zgromadzenie zbioru przepisów regulujących prawa i obowiązki pracodawcy i pracowników związane $\mathrm{z}$ konsumpcją tych substancji, $\mathrm{w}$ tym przepisów prawa państwowego oraz wewnętrznych przepisów firmy. Wewnętrzne przepisy powinny uwzględniać identyfikowane $\mathrm{w}$ firmie problemy i wynikające $\mathrm{z}$ nich potrzeby oraz powstawać w toku konsultacji z członkami kadry oraz podwładnymi. Przepisy takie powinny jasno określać m.in. to, co jest zabronione, konsekwencje złamania przepisu, prawa pracowników, procedury związane $\mathrm{z}$ chęcią wyrażenia przez pracownika niezadowolenia $\mathrm{z}$ programu, sposoby postępowania w przypadkach, gdy pracownik jest podejrzewany o zażywanie środków psychoaktywnych, regulacje dotyczące ochrony danych i informacji dotyczących konkretnych pracowników (szczególnie danych wrażliwych), formy wsparcia przewidziane dla osób uzależnionych, które podejmą leczenie, warunki powrotu do pracy w czasie terapii lub po jej zakończeniu (Korzeniowska, Puchalski, Goszczyńska 2013: 35-36). Na tej podstawie możliwe jest wprowadzenie wielu działań wynikających ze szczegółowo określonej polityki firmy w zakresie przeciwdziałania zażywaniu substancji psychoaktywnych przez pracowników.

Jednym z elementów związanych z egzekwowaniem polityki narkotykowej jest kontrola pracowników pod kątem zażywania narkotyków. Taką możliwość dają testy wykrywające narkotyki. Testowanie na obecność narkotyków w miejscu pracy jest obecnie uznaną 
praktyką w Stanach Zjednoczonych i w wielu innych krajach. Duże i małe firmy oraz korporacje rutynowo sprawdzają kandydatów do pracy, a pomyślne przejście testu na narkotyki często jest warunkiem wstępnym do zatrudnienia. Po zatrudnieniu pracownicy poddawani są losowym testom. Powodami testowania na obecność narkotyków mogą być: niska wydajność, utracone zyski, wadliwe produkty, nieobecność w pracy, wypadki w miejscu pracy, wysoka rotacja pracowników, kradzież lub szpiegostwo. Tradycyjne testy narkotykowe w miejscu pracy polegają na pobraniu próbki moczu i wysłaniu jej do laboratorium w celu wykonania analizy. Nowe podejście daje możliwość testowania na miejscu na podstawie dostępności wielu prostych zestawów (Armbruster 2002: 25). Testy na obecność narkotyków są wyrazem polityki związanej $\mathrm{z}$ brakiem tolerancji dla używania narkotyków i bycia pod ich wpływem w miejscu zatrudnienia. Ważne jest, aby nie były to jedyne działania prowadzone w firmie. Dlatego oprócz rygorystycznej kontroli powinny być prowadzone działania informacyjne, edukacyjne oraz wspierające. Kompleksowe programy powinny stawiać sobie za cel zminimalizowanie używania narkotyków wśród pracowników, ale również pomoc osobom uzależnionym i jednocześnie powracającym do pracy po odbytej terapii.

Zatem ważne jest, aby oprócz programów promocji zdrowia w obszarze aktywności fizycznej, zdrowego odżywiania się itp. firmy realizowały programy profilaktyczne dotyczące sięgania po legalne i nielegalne substancje psychoaktywne. Jednak nieczęsto tak się dzieje w praktyce i kwestia zażywania narkotyków nie jest przedmiotem takiej samej uwagi, jak inne programy z zakresu promocji zdrowia.

\section{Standardy oddziaływań profilaktycznych w miejscu pracy}

Wiele czynników może stanowić przeszkodę we wdrażaniu programów z zakresu profilaktyki społecznej w miejscu pracy. W celu przezwyciężenia owych trudności można zastosować takie strategie działań, jak ustalenie płaszczyzny porozumienia z zakładami pracy poprzez przeprowadzenie diagnozy problemów w celu ulepszenia lub opracowania programu tak, aby wpisywał się on w aktualne potrzeby, omawianie treści konkretnych programów zamiast mówienia o koncepcjach i typach programów oraz wypracowanie długoletnich dobrych stosunków z zakładami pracy (Macdonald, Wells 1999). 
Zminimalizowanie trudności związanych z realizacją programów jest również możliwe dzięki korzystaniu $\mathrm{z}$ rozwiązań udokumentowanych jako skuteczne oraz odwoływaniu się do standardów jakości. Ze względu na nieliczne programy profilaktyczne stosowane w Polsce w wielu miejscach pracy nie zostały wypracowane szczegółowe standardy owych oddziaływań. Warto zatem czerpać z ogólnych standardów dotyczących działań profilaktycznych oraz doświadczeń zagranicznych opartych na dowodach naukowych.

Standardy jakości programów profilaktyki uzależnień adresowane są do wszystkich osób zainteresowanych tworzeniem skutecznej profilaktyki uzależnień opartej na dowodach naukowych. Odnoszą się do całego cyklu projektowego programu profilaktycznego oraz określają szczegółowe wytyczne związane z każdym z ośmiu etapów (ocena potrzeb, ocena zasobów, ramy programu, konstrukcja interwencji, zarządzanie i mobilizacja zasobów, realizacja i monitoring, ewaluacje końcowe, rozpowszechnianie). Istotne jest, aby działania realizowane w ramach profilaktyki uzależnień spełniały kryteria standardów, powinny dążyć do zapobiegania lub opóźniania inicjacji narkotykowej, promowania abstynencji, redukowania częstotliwości używania i/lub ilości używanych substancji, zapobiegania przechodzeniu na coraz bardziej niebezpieczne i szkodliwe wzory używania i/lub zapobiegania bądź redukowania negatywnych skutków używania (Węgrzecka-Giluń, Malczewski 2011: 35-36, 43-46).

Departament Zdrowia i Usług Społecznych Stanów Zjednoczonych proponuje modelowy plan kompleksowego programu profilaktyki zażywania narkotyków przez pracowników w miejscu pracy, który powinien się opierać na pięciu zasadniczych elementach: opracowanie w formie jakiegoś dokumentu kompleksowej polityki, szkolenie dla osób zarządzających, edukacja pracowników, dostępność programów pomocy dla pracowników, identyfikacja nielegalnych użytkowników narkotyków, w tym stosowanie testów narkotykowych. Fundamentem modelu jest polityka, która oferuje pomocną dłoń, jednocześnie wyraźnie informując, że stosowanie nielegalnych substancji nie będzie tolerowane (por. Model Plan for a Comprehensive Drug-Free Workplace Program 1989).

Istotnym elementem występującym w Stanach Zjednoczonych są zasoby oddziału programów roboczych SAMHSA (Division of Workplace Programs of Substance Abuse and Mental Health Services 
Administration), w których znajdują się informacje mogące pomóc pracodawcom $\mathrm{w}$ opracowaniu, implementacji oraz utrzymaniu skutecznych programów mających na celu stworzenie miejsca pracy wolnego od narkotyków. Programy te często łączą profilaktykę sięgania po narkotyki w miejscu pracy z praktykami zdrowotnymi opartymi na dowodach naukowych, w tym programami wybranymi $\mathrm{z}$ narodowego rejestru programów i praktyk opartych na dowodach naukowych SAMHSA (National Registry od Evidence-Based Programs and Practices - NREPP) (por. About the Division of Workplace Programs 2019). Dodatkowo baza danych NREPP zawiera również programy profilaktyczne, w tym te, które były przedmiotem badań naukowych.

Istotnym elementem przy wprowadzaniu programów profilaktycznych realizowanych $\mathrm{w}$ miejscu pracy jest adaptacja programów, które zostały udokumentowane jako skuteczne.

Możemy wyróżnić cztery etapy procesu wprowadzania działań o empirycznie potwierdzonej skuteczności do praktyki: szkolenie, adaptacja (etap obejmujący podejmowanie decyzji i działań związanych z wyborem innowacyjnych rozwiązań i ich ewaluacja), implementacja (strategia działania, której celem jest adaptacja programu opartego na badaniach empirycznych i jego integracja z wcześniej podejmowanymi działaniami placówki, co w konsekwencji będzie prowadziło do zmian w jej funkcjonowaniu) i udoskonalenie praktyki. Implementacja będzie stanowiła ważny element pomiędzy podjęciem decyzji o adaptacji programu i trwałym wprowadzeniem go do działań realizowanych przez firmę. Możemy wyróżnić czynniki, które będą zwiększały powodzenie implementacji. Są to: jakość i intensywność szkolenia oraz wsparcie i poparcie osób wprowadzających innowacje, pozytywne nastawienie do wprowadzanych działań oraz czas i pieniądze. Dodatkowo, wprowadzenie programów opartych na dowodach jest możliwe w dobrze zarządzanych placówkach. Dobre zarządzanie, zaangażowanie i wsparcie kierownictwa to warunki konieczne do pozyskania i dostępności innowacyjnych programów, implementacji, utrwalenia wprowadzanych skutecznych rozwiązań, pozytywnych postaw wobec wprowadzanych działań, przeznaczenia środków finansowych, monitorowania ich jakości (Flynn, Simpson 2013).

$\mathrm{Na}$ skuteczne wprowadzenie działań profilaktyki sięgania po narkotyki w firmie składa się wiele elementów, które muszą ze sobą współgrać. Ważne jest, aby wprowadzany program był oparty na 
dowodach naukowych, lecz również istotny jest pozytywny klimat w miejscu implementacji, gdyż nawet najskuteczniejszy program nie przyniesie oczekiwanych rezultatów, jeśli nie będzie zaakceptowany.

\section{Zakończenie}

Planując i wdrażając programy profilaktyczne kładzie się obecnie coraz większy nacisk na to, aby były one oparte na dowodach naukowych. Nurt evidence-based practice jest coraz bardziej istotny przy implementacji działań z zakresu profilaktyki. Współcześnie w Polsce prowadzone są nieliczne programy z zakresu profilaktyki sięgania po narkotyki w miejscach pracy. Nie ma także programów kierowanych do pracowników, które byłyby rekomendowane ze względu na ich oparcie na dowodach naukowych. Ważnym zatem obszarem jest tworzenie i ewaluacja takich programów lub też adaptacja programów istniejących w innych krajach.

Wśród korzyści dla firmy wynikających z kompleksowego rozwiązywania trudności pracowników wymienić można: oszczędności kapitałowe związane m.in. ze zmniejszonymi kosztami absencji chorobowej, wypadkami zawodowymi, oszczędnością czasu pracy; poprawę i rozwój jakości personelu poprzez poprawę stanu zdrowia i obniżenie ryzyka jego utraty, obniżenie poziomu stresu, osłabienie lęków przed zmianą, otwarcie na innowacje, podwyższenie samooceny, poczucia własnej wartości, odpowiedzialności, rozwój kompetencji; poprawę wewnętrznych relacji społecznych, m.in.: usprawnienie systemu informacji i komunikacji wewnętrznej firmy, kreowanie liderów i grup zadaniowych w obszarach związanych ze zdrowiem, rozwój ich zaangażowania, wzmocnienie więzi i relacji międzyludzkich, wzrost akceptacji ze strony personelu dla celów i działań firmy, integracja z organizacją; wsparcie dla działań wizerunkowych i marketingowych (Korzeniowska, Puchalski, Goszczyńska 2013: 12).

Innym ważnym powodem wprowadzania programów profilaktycznych w miejscu pracy jest to, że w miejscu pracy można dotrzeć do pracowników będących rodzicami. Dostępność rodziców i próba ich zaangażowania w programy profilaktyczne mające na celu wzrost kompetencji może się przyczynić do ograniczenia sięgania po narkotyki przez dzieci i młodzież. Przykładem programu skierowanego do rodziców w miejscu pracy jest program Parenting Partnership, 
prowadzony w 24 jednogodzinnych sesjach. Kolejny program to The K.I.D.S. (Kids in a Drug-Free Society), który został opracowany, aby zapewnić pracującym rodzicom motywację i umiejętności niezbędne do skutecznego rozmawiania $\mathrm{z}$ dziećmi na tematy alkoholu, tytoniu i innych narkotyków. Centralnym elementem jest tu program szkolenia w miejscu pracy, mający pomóc rodzicom wzmocnić więzi rodzinne, ustalić jasne oczekiwania i wzmacniać w dzieciach umiejętność przeciwstawiania się presji rówieśników (Cook, Schlenger 2002: 118-119).

Realizacja programów profilaktyki w miejscu pracy jest równie ważna jak prowadzenie działań profilaktycznych w szkole czy w środowisku lokalnym. Dlatego też istnieje ogromna potrzeba prowadzenia badań związanych z tym obszarem. Również istotne jest projektowanie, realizacja i ewaluacja nowych programów bazujących na standardach jakości w celu wypracowania rozwiązań opartych na dowodach naukowych oraz adaptacja i implementacja programów już istniejących i wywodzących się z nurtu evidence-based practice.

\section{Bibliografia}

About the Division of Workplace Programs. 2019. <https://www.samhsa.gov/ workplace/about> [dostęp: 20.06.2019].

Armbruster D. (2002). On-Site Workplace Drug Testing, [w:] A.J. Jenkins, B.A. Goldberger (red.), On-Site Drug Testing, Totowa (N.J.): Humana Press, s. 25-35.

Bennett J.B, Lehman W.E.K., Reynolds G.S. (2000). Team Awareness for Workplace Substance Abuse Prevention: The Empirical and Conceptual Development of a Training Program, „Prevention Science”, t. 1, nr 3, s. 157172. DOI: $10.1023 / \mathrm{a}: 1010025306547$.

Breen G.-M., Matusitz J. (2009). An Updated Examination of the Effects of Illegal Drug Use in the Workplace, "Journal of Human Behavior in the Social Environment”, t. 19, nr 4, s. 434-447. DOI: 10.1080/ 10911350902870183.

Cook R., Schlenger W. (2002). Prevention of Substance Abuse in the Workplace: Review of Research on the Delivery of Services, „The Journal of Primary Prevention”, t. 23, nr 1, s. 115-142. DOI: 0278-095X/02/0900-0115/0.

Europejski raport narkotykowy. Tendencje i osiagnięcia. (2019). Luksemburg: Urząd Publikacji Unii Europejskiej, <http://www.emcdda.europa.eu/ system/files/publications/11364/20191724_TDAT19001PLN_PDF. pdf> [dostęp: 20.06.2019]. 
Flynn P.M., Simpson D.D. (2013). Adaptacja i wdrażanie terapii opartej na dowodach naukowych, [w:] P.M. Miller (red.), Terapia uzależnien. Metody oparte na dowodach naukowych, przeł. E. Józefowicz, Warszawa: Wydawnictwo Uniwersytetu Warszawskiego, s. 412-430.

Goszczyńska E. (2013). Regulacje prawne dotyczace konsumpcji alkoholu i narkotyków w pracy, „Medycyna Pracy”, nr 64(4), s. 593-608, http://dx.doi. org/10.13075/mp.5893.2013.0045.

Informator dla zaktadów pracy na temat problemów używania substancji psychoaktywnych przez pracowników. Adaptacji treści podręcznika do polskich warunków dokonali: E. Goszczyńska, E. Korzeniowska, K. Knol, P. Pankonin, P. Plichta, J. Pyżalski, K. Puchalski, P. Wojtaszczyk, $<$ https://promocjazdrowiawpracy.pl/wp-content/uploads/2018/10/ informator-dla-pracodawcow-mepmis-2-1.pdf> [dostęp: 20.06.2019].

Korzeniowska E., Puchalski K., Goszczyńska E. (2013). Zarzadzanie problemem konsumpcji tytoniu, alkoholu $i$ innych substancji psychoaktywnych w firmie. Poradnik dla pracodawców i menadżerów, Łódź, <https://promocjazdrowiawpracy.pl/wpcontent/uploads/2018/10/poradnik_pracodawcy.pdf> [dostęp: 20.06.2019].

Macdonald S., Wells S. (1999). Strategie profilaktyki w miejscu, pracy: doświadczenia z badań nad oceną potrzeb w pięciu zakładach pracy, „Alkoholizm i Narkomania”, nr 1(34), s. 111-117.

Mielecka-Kubień Z. (2017). Oszacowanie kosztów spotecznych uży wania narkotykóww Polscew2015r., <https://www.cinn.gov.p1/portal?id=1285104> [dostęp: 20.06.2019].

Model Plan for a Comprehensive Drug-Free Workplace Program. (1989). $<$ https://www.samhsa.gov/sites/default/files/workplace/ModelPlan508. pdf> [dostęp: 20.06.2019].

Puchalski K., Korzeniowska E. (2017). Promocja zdrowia w zaktadach pracy w Polsce w 2015 r. - diagnoza na podstawie reprezentatywnego badania firm zatrudniajacych powyżej 50 pracowników, „Medycyna Pracy”, nr 68(2), s. 229-246. DOI: 10.13075/mp.5893.00532.

Raport o stanie narkomanii w Polsce. (2018). Warszawa: Krajowe Biuro ds. Przeciwdziałania Narkomanii, <https://www.cinn.gov.pl/portal?id= 15\&res_id=1417507> [dostęp: 20.06.2019].

Sorensen J.L., Hettema J.E., Larios S. (2018). Co to jest terapia oparta na dowodach naukowych?, [w:] P.M. Miller (red.), Terapia uzależnień. Metody oparte na dowodach naukowych, przeł. E. Józefowicz, Warszawa: Wydawnictwo Uniwersytetu Warszawskiego, s. 23-40.

Van Hasselt M., Keyes V., Bray J., Miller T. (2015). Prescription Drug Abuse and Workplace Absenteeism: Evidence from the 2008-2012 National Survey on Drug Use and Health, "Journal of Workplace Behavioral Health", nr 30, s. 379-392. DOI: 10.1080/15555240.2015.1047499. 
Węgrzecka-Giluń J., Malczewski A. (red.) (2011). Europejskie standardy jakości w profilaktyce uzależnień. Podręcznik dla specjalistów profilaktyki uzależnień, Warszawa: Krajowe Biuro ds. Przeciwdziałania Narkomanii. Wynne R., De Broeck V., Vandenbroek K., Leka S., Jain A., Houtman I., McDaid D., Park A.-L. (2017). Promowanie zdrowia psychicznego w miejscu pracy. Wytyczne dotyczace wdrażania kompleksowego podejścia, Luksemburg: Urząd Publikacji Unii Europejskiej.

\author{
ADRES DO KORESPONDENCJ \\ Dr Małgorzata Piasecka \\ Uniwersytet Jagielloński \\ Instytut Pedagogiki \\ e-mail: malgorzata.piasecka@uj.edu.pl \\ Dr kukasz Szwejka \\ Uniwersytet Jagielloński \\ Instytut Pedagogiki \\ e-mail: lukasz.szwejka@uj.edu.pl
}

